\title{
ADRENAL FUNCTION IN CHILDREN
}

\author{
BY \\ BARBARA E. CLAYTON, R. W. H. EDWARDS and A. G. C. RENWICK \\ From the Department of Chemical Pathology, The Hospital for Sick Children, Great Ormond Street, London
}

(RECEIVED fOR PUblication AUgust 16, 1962)

Attention has been drawn to the rarity of reports on Addison's disease in children by Greenberg (1958) and Szczepańska and Sapiecha (1959). The diagnosis can be difficult to make since features such as anorexia, recurrent dehydration and general debility are not specific for the condition (Talbot, Sobel, McArthur and Crawford, 1952). Often the diagnosis is made in retrospect or after the child has been under clinical surveillance for several years (Greenberg, 1958).

Chemical methods for assessing adrenal cortical function have been applied frequently in adults (Nelson, Samuels, Willardson and Tyler, 1951; Gordon, Horwitt and Segaloff, 1954) and patterns of steroid response to adrenocorticotrophic (ACTH) stimulation in various pathological states have been clearly defined (Prunty, 1956).

In children, as in adults (Prunty, 1956), there is considerable day-to-day variation in the excretion of steroids. Since the urinary excretion of 17-ketosteroids and 17-hydroxycorticoids is so low in children (Prout and Snaith, 1958; Norymberski, Stubbs and West, 1953), it is unwise to diagnose defective adrenal function by the measurement of resting steroid excretions. It has been observed in adults that zero levels of urinary steroids and blood corticoids are frequently not encountered in Addison's disease (Laidlaw, Reddy, Jenkins, Haydar, Renold and Thorn, 1955; Bayliss, 1955). It is, therefore, necessary to measure the response of the adrenal gland to injected ACTH in an attempt to demonstrate degrees of adrenal failure.

The test has been employed in several ways in children. Gottfried, Bogin and Levycky (1957) gave one injection of ACTH in gelatin solution at 10 p.m. and determined the urinary excretion of 17-hydroxycorticoids during the following eight hours. Though a definite rise in steroid excretion was obtained in normal children, the response was in fact so small that it would be difficult to detect anything other than complete adrenal failure. Ely, Raile, Bray and Kelley (1954) measured the 17-hydroxycorticoids in the plasma before and after ACTH. The values obtained showed a wide variation among individuals and the authors considered that rigid interpretation of the results was unwise as some normal children gave a poor response. The results obtained by Steiker, Bongiovanni, Eberlein and Leboeuf (1961). employing a similar type of test, were more regular, and impaired adrenal responses could be diagnosed.

In the work to be described, three days' stimulation with ACTH was employed, since it may take several days to elicit a near maximal response (Prunty, 1956). Urinary excretion of corticosteroids was studied in preference to blood because blood may not be collected at the peak of the response and diurnal variations in 17-hydroxycortizoid levels may affect the size of the response. Also, no really satisfactory micromethod using finger-prick blood for 17-hydroxycorticoids is yet available.

\section{Method of Performing ACTH Test}

The test was begun at 10 a.m. Four consecutive 24-hour urines were collected using a few drops of chloroform as preservative. Twenty physiological units of ACTH gel (H.P. Acthar gel, Armour Laboratories Ltd.) were administered intramuscularly at 10 a.m. and 6 p.m. on the second, third and fourth days. In the course of several hundred tests no unpleasant side-effect has ever been observed.

Two batches of ACTH of porcine origin have been employed.

1. CK 2501 Initial potency 40 I.U. $/ \mathrm{ml}$. Limits $=37 \cdot 1-42 \cdot 9$ I.U. $/ \mathrm{ml}$. Fiducial limits $(\mathrm{p}=0.95) 87-115 \%$.

2. EE 1004 Initial potency $38 \cdot 4 \mathrm{I} . \mathrm{U} . / \mathrm{ml}$. Limits $=34 \cdot 8-42 \cdot 4$ I.U. $/ \mathrm{ml}$. Fiducial limits $(p=0.95) 87-106 \%$.

Hence 20 units were given in 0.5 and $0.52 \mathrm{ml}$. gel of batches CK 2501 and EE 1004, respectively; a tuberculin syringe was used for injection.

Urinary 17-ketosteroids were determined by the second method of Prout and Snaith (1958) and total 17-hydroxycorticoids by the method of Appleby, Gibson, Norymberski and Stubbs (1955).

\section{Results and Discussion}

ACTH tests were performed on 30 children aged 5 months to 14 years. None of the children 
TABLE 1

ACTH TESTS IN SERIES OF CHILDREN WITH NO CLINICAL FEATURES OF ADRENAL DEFICIENCY

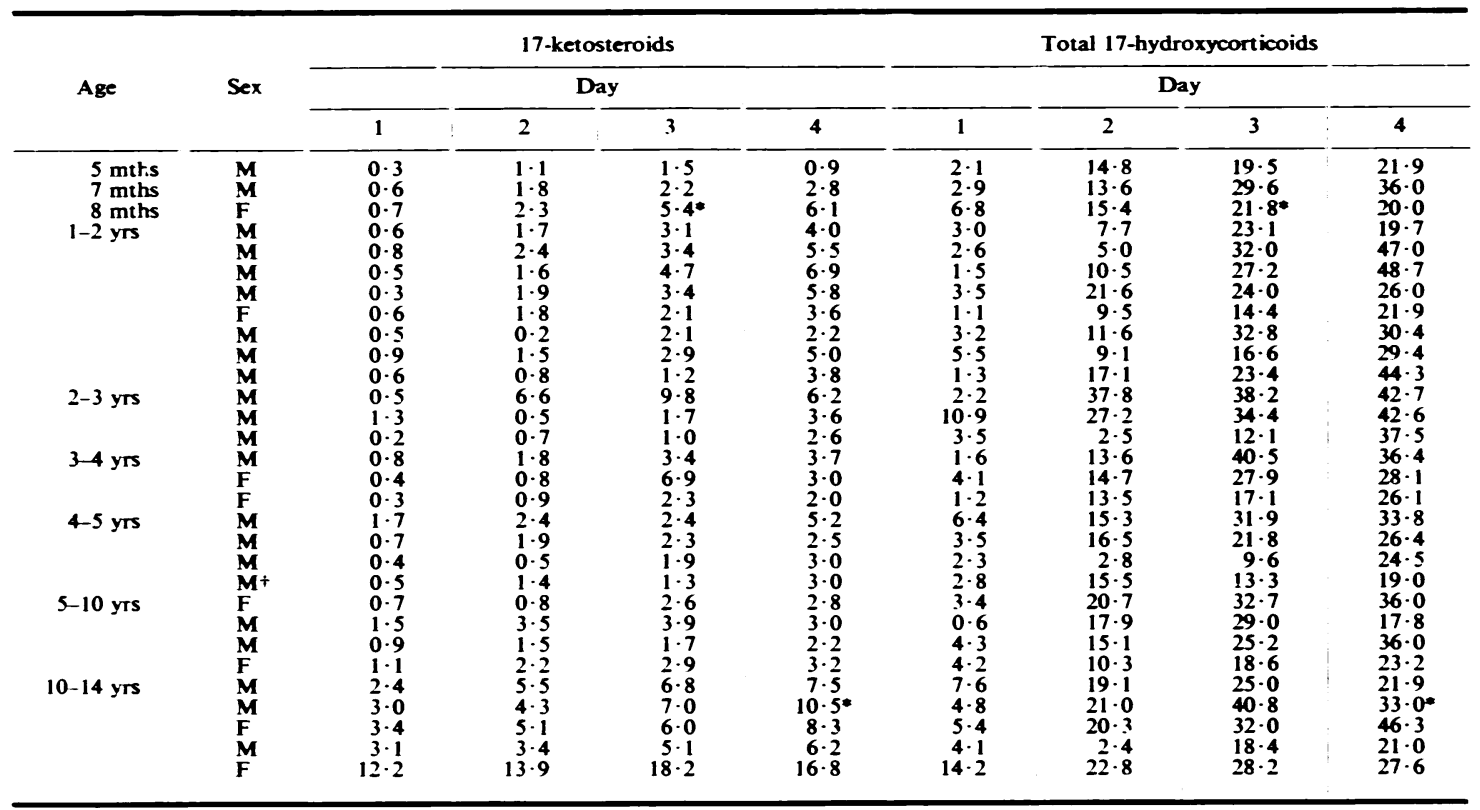

Day 1 = baseline: Days 2, 3, $4=$ on ACTH.

All results are in mg 24 hours.

- A few ml. of urine were lost from these collections.

$\div$ Only child giving a response of less than $20 \mathrm{mg}$. corticaids during the second or third day of ACTH (see text).

exhibited any clinical features suggestive of adrenal disorder.

The results of the tests are given in Table 1. No variation in response was seen with age, and the eight girls in the group did not give responses significantly different from those of the boys; these observations confirm those of Steiker et al. (1961). As shown by others (e.g. Gottfried et al., 1957), the total 17-hydroxycorticoids were a more sensitive index than the 17-ketosteroids and apart from research purposes there appears to be no additional benefit to be gained by estimating the 17-ketosteroids as well as the corticoids when looking for adrenal hypofunction. The maximal corticoid excretion occurred during the second or third days of ACTH injections and apart from one exception always reached at least $20 \mathrm{mg}$. $/ 24$ hours on one or other of these days.

One child with all the classical symptoms and signs of Addison's disease was tested (patient A, Table 2) and showed negligible response, the corticoid output on the last day of ACTH reaching only $2.9 \mathrm{mg}$. $/ 24$ hours. The test has been used in many patients and in four of them in whom poor responses were obtained (Table 2 ), adrenal cortical atrophy was found at autopsy, the time between the test and autopsy being variable. It is of importance that in these patients a response to ACTH did in fact occur, but it was much less than the normal. and it is apparent that the test can be used to diagnose more subtle degrees of adrenal failure than frank Addison's disease.

If a test of adrenal function is required in a patient who is receiving steroids, he is transferred to an equivalent dose of oral dexamethasone $(0.5$ to $0.75 \mathrm{mg}$. is equivalent to $25 \mathrm{mg}$. cortisone acetate) begun two days before the test and continuing throughout it. Examples of tests performed during or following the withdrawal of steroid therapy are given in Table 3 and illustrate the well-known suppression of adrenal steroid secretion by exogenous steroid therapy (Meakin, Tantongco, Crabbé, Bayles and Nelson, 1960).

In the course of the routine investigation of children (1) whose stature was less than normal and in whom hypopituitarism was suspected, or (2) who presented with hypoglycaemia, a number have shown an impaired response to ACTH. Examples of these are given in Table 3, and include patient $C$ whose results are also shown in Table 2 . 
TABLE 2

ACTH TESTS IN ADRENAL CORTICAL DEFICIENCY

\begin{tabular}{|c|c|c|c|c|c|c|c|c|c|c|c|c|}
\hline \multirow{3}{*}{ Patient } & \multirow{3}{*}{ Sex } & \multirow{3}{*}{ Age } & \multicolumn{4}{|c|}{$\begin{array}{c}\text { 17-ketosteroids } \\
\text { (urinary; mg-/24 hrs) }\end{array}$} & \multicolumn{4}{|c|}{$\begin{array}{l}\text { Total 17-hydroxycorticoids } \\
\text { (urinary; mg/24 hrs) }\end{array}$} & \multirow{3}{*}{$\begin{array}{l}\text { Interval } \\
\text { Between } \\
\text { ACTH } \\
\text { Test and } \\
\text { Autopsy }\end{array}$} & \multirow{3}{*}{ Comments } \\
\hline & & & \multicolumn{3}{|c|}{ Day } & & \multicolumn{3}{|c|}{ Day } & \multirow{3}{*}{$\frac{4}{2 \cdot 9}$} & & \\
\hline & & & 1 & 2 & 3 & 4 & 1 & 2 & 3 & & & \\
\hline $\mathbf{A}$ & $\mathbf{M}$ & 10 yrs & $0 \cdot 1$ & 0.7 & $1 \cdot 0$ & $1 \cdot 1$ & $1 \cdot 4$ & $1 \cdot 5$ & $1 \cdot 4$ & & & $\begin{array}{l}\text { Symptoms and signs of classica! } \\
\text { Addison's disease }\end{array}$ \\
\hline B & $\mathbf{M}$ & $5 \mathrm{mths}$ & $0 \cdot 2$ & 0.5 & 0.6 & 0.4 & $1 \cdot 1$ & $3 \cdot 0$ & $3 \cdot 5$ & $5 \cdot 6$ & $1 ! \mathrm{mth}$ & $\begin{array}{l}\text { Typus de Lange; atrophy of zona } \\
\text { fasciculata and zona reticularis } \\
\text { found at autopsy }\end{array}$ \\
\hline C & $\mathbf{M}$ & $14 \mathrm{mths}$ & $0 \cdot 3$ & 0.2 & $0 \cdot 3$ & 0.5 & 0.5 & $3 \cdot 6$ & $5 \cdot 6$ & $10 \cdot 3$ & ? wk & $\begin{array}{l}\text { Dwarfism and fits. associated with } \\
\text { hypogdycaemia; atrophy of zona } \\
\text { fasciculata and zona reticularis } \\
\text { found at autopsy }\end{array}$ \\
\hline $\mathbf{D}$ & $\mathbf{M}$ & 5 yrs & $0 \cdot 3$ & $0 \cdot 8$ & 0.8 & $1 \cdot 0$ & $1 \cdot 7$ & $4 \cdot 8$ & $4 \cdot 2$ & $6 \cdot 1$ & $2 ! \mathrm{yr}$ & $\begin{array}{l}\text { Attacks of recurrent vomiting: } \\
\text { autopsy showed adrenals almost } \\
\text { entirely atrophied }\end{array}$ \\
\hline $\mathbf{E}$ & $\mathbf{M}$ & 5 yrs & $1 \cdot 3$ & $1 \cdot 5$ & $1 \cdot 1$ & 0.6 & $2 \cdot 5$ & $4 \cdot 4$ & $4 \cdot 7$ & $5 \cdot 5$ & 3 wk & $\begin{array}{l}\text { Failure to thrive and vomiting; large } \\
\text { suprasellar tumour with raised } \\
\text { intracranial pressure; at autopsy } \\
\text { adrenals weighed } 6 \mathrm{~g} \text {. (normal } \\
8-10 \mathrm{~g} \text {.) and the zona glomerulosa } \\
\text { was hypoplastic with extensive } \\
\text { vacuolation of zona fasciculata }\end{array}$ \\
\hline
\end{tabular}

TABLE 3

ACTH TESTS AND EFFECT OF STEROID THERAPY

\begin{tabular}{|c|c|c|c|c|c|c|c|c|c|c|c|c|c|}
\hline \multirow{3}{*}{ Patient } & \multirow{3}{*}{$\operatorname{Sex}$} & \multirow{3}{*}{ Age } & \multirow{3}{*}{ Disease } & \multirow{3}{*}{$\begin{array}{l}\text { Duration of } \\
\text { Steroid Therapy }\end{array}$} & \multirow{3}{*}{$\begin{array}{l}\text { Stero:d } \\
\text { Treatment } \\
\text { Immediately } \\
\text { Before Test }\end{array}$} & \multicolumn{4}{|c|}{$\begin{array}{l}\text { 17-ketosteroids } \\
\text { (urinary; mg-/24 hrs) }\end{array}$} & \multicolumn{4}{|c|}{$\begin{array}{l}\text { Total 17-hydroxycorticoids } \\
\text { (urinary; mg } 24 \text { hrs) }\end{array}$} \\
\hline & & & & & & \multirow[b]{2}{*}{1} & \multicolumn{2}{|c|}{ Day } & \multirow[b]{2}{*}{4} & \multicolumn{3}{|c|}{ Day } & \multirow[b]{2}{*}{4} \\
\hline & & & & & & & 2 & 3 & & 1 & 2 & 3 & \\
\hline $\mathbf{F}$ & $\mathbf{M}$ & 12 yrs & Asthma & $\begin{array}{c}19 \mathrm{mths} \\
\text { (about } 50 \mathrm{~g} \text {. cortisone) }\end{array}$ & $75 \mathrm{mg}$. & $1 \cdot 6$ & $1 \cdot 0$ & 0.9 & $1 \cdot 2$ & 0 & $0 \cdot 2$ & $1 \cdot 7$ & $2 \cdot 7$ \\
\hline & & & & $\begin{array}{c}\text { Two mth since ACTH } \\
\text { test above }(2 \mathrm{~g} \text {. } \\
\text { cortisone })\end{array}$ & $\begin{array}{l}4 C \mathrm{mg} \text {. } \\
\text { cortisone daily os }\end{array}$ & $0 \cdot 7$ & $1 \cdot 3$ & $1 \cdot 5$ & 0.7 & $3 \cdot 7$ & $5 \cdot 9$ & $16 \cdot 8$ & $18 \cdot 3$ \\
\hline G & $\mathbf{M}$ & 12 yrs & $\begin{array}{l}\text { Sclero- } \\
\text { derma }\end{array}$ & $\begin{array}{l}19 \text { mths } \\
\text { (atout } 6 \mathrm{~g} . \text { prednisone) }\end{array}$ & $\begin{array}{l}60 \mathrm{mg} \text {. } \\
\text { prednisone daily os }\end{array}$ & $2 \cdot 5$ & $3 \cdot 2$ & - & $3 \cdot 9$ & $3 \cdot 9$ & $3 \cdot 9$ & - & $9 \cdot 7$ \\
\hline $\mathbf{H}$ & $\mathbf{M}$ & $8 \geqq$ yrs & $\begin{array}{l}\text { Still's } \\
\text { disease }\end{array}$ & $\begin{array}{c}4 \text { yrs } \\
\text { (about } 14 \mathrm{~g} \text {. prednisone) }\end{array}$ & $\begin{array}{l}5 \mathrm{mg} \text {. } \\
\text { prednisone dailv os }\end{array}$ & 0.5 & 0.6 & $1 \cdot 4$ & $1 \cdot 1$ & $1 \cdot 6$ & $3 \cdot 8$ & $9 \cdot 7$ & $10 \cdot 9$ \\
\hline \multirow[t]{2}{*}{ I } & \multirow[t]{2}{*}{$\mathbf{M}$} & \multirow[t]{2}{*}{$31 \mathrm{yrs}$} & \multirow[t]{2}{*}{ Nephrosis } & \multirow{2}{*}{$\begin{array}{c}7 \text { mths (about } 2 \cdot 5 \mathrm{~g} . \\
\text { triamcinolone) } \\
11 \text { mth since } \\
\text { ACTH test above } \\
\text { (!-3 g. prednisone) }\end{array}$} & \multirow{2}{*}{$\begin{array}{c}\text { None for previous } \\
4 \text { wks } \\
2 \cdot 5 \mathrm{mg} \text {. } \\
\text { prednisone daily os }\end{array}$} & $0 \cdot 3$ & 0.4 & 0.4 & $0 \cdot 8$ & $0 \cdot 5$ & $1 \cdot 7$ & $6 \cdot 0$ & $15 \cdot 0$ \\
\hline & & & & & & 0.6 & $0 \cdot 2$ & 0.4 & 0.6 & $1 \cdot 0$ & $3 \cdot 3$ & $2 \cdot 6$ & $7 \cdot 5$ \\
\hline J & $\mathbf{M}$ & 4 yrs & Nephrosis & $\begin{array}{l}23 \mathrm{mths} \\
\text { (very variable dosage- } \\
\text { up to } 35 \mathrm{mg} \text {. prednisone } \\
\text { or prednisolone daily) }\end{array}$ & $\begin{array}{l}\text { None for previous } \\
5 \text { mths }\end{array}$ & $0 \cdot 2$ & 0.5 & $2 \cdot 2$ & $3 \cdot 1$ & $2 \cdot 2$ & $7 \cdot 3$ & $17 \cdot 0$ & $35 \cdot 1$ \\
\hline
\end{tabular}

In two of the patients ( $U$ and $V$ ) the test was repeated 15 and two months later respectively, and a poor response was obtained on each occasion.

Other methods for the diagnosis of adrenal hypofunction are indirect and include the measurement of (1) plasma and urinary electrolytes and blood urea, (2) absolute eosinophil counts, (3) ability to excrete a water load and (4) insulin tolerance. In milder adrenal hypofunction (1) and (2) may be normal. A water load test is potentially dangerous in a patient in whom adrenal deficiency is suspected, since water intoxication may be produced, and in any case is fraught with difficulties in a young child who cannot empty his bladder to order. Insulin tolerance is a useful test and reasonably safe in children if performed by the subcutaneous route 
TABLE 4

EXAMPLES OF POOR RESPONSES TO ACTH IN CHILDREN PRESENTING WITH HYPOGLYCAEMIA OR SHORT STATURE

\begin{tabular}{|c|c|c|c|c|c|c|c|c|c|c|c|}
\hline \multirow[t]{2}{*}{ Patient } & \multirow[t]{2}{*}{ Sex } & \multirow[t]{2}{*}{ Age } & \multicolumn{4}{|c|}{$\begin{array}{l}\text { 17-ketosteroids } \\
\text { (urinary; mg./24 hrs) } \\
\text { (Day! }\end{array}$} & \multicolumn{4}{|c|}{$\begin{array}{l}\text { Total 17-hydroxycorticoids } \\
\text { (urinary; mg./24 hrs) } \\
\text { (Day) }\end{array}$} & \multirow[t]{2}{*}{ Comments } \\
\hline & & & 1 & 2 & 3 & 4 & 1 & 2 & 3 & 4 & \\
\hline C & $\mathbf{M}$ & $14 \mathrm{mths}$ & $\mathbf{0} \cdot \mathbf{3}$ & $0 \cdot 2$ & $0 \cdot 3$ & 0.5 & 0.5 & $3 \cdot 6$ & $5 \cdot 6$ & $10 \cdot 3$ & $\begin{array}{l}\text { Short stature, and fits associated with hypo- } \\
\text { glycaemia (see Table 2) }\end{array}$ \\
\hline $\mathbf{K}$ & $\mathbf{F}$ & $18 \mathrm{mths}$ & $0 \cdot 3$ & $0 \cdot 5$ & $1 \cdot 0$ & $1 \cdot 0$ & 0.9 & $2 \cdot 0$ & $8 \cdot 0$ & $12 \cdot 0$ & $\begin{array}{l}\text { Healthy-looking child; fits associated with } \\
\text { hypoglycaemia developed } 3 \text { weeks before } \\
\text { admission }\end{array}$ \\
\hline $\mathbf{L}$ & $\mathbf{M}$ & 22 mths & 0.4 & $1 \cdot 0$ & $1 \cdot 6$ & $3 \cdot 5$ & $2 \cdot 6$ & $6 \cdot 4$ & $6 \cdot 8$ & $13 \cdot 5$ & Small stature; poor appetite; mental retardation \\
\hline $\mathbf{M}$ & $\mathbf{F}$ & $25 \mathrm{mths}$ & $0 \cdot 2$ & $0 \cdot 5$ & $1 \cdot 1$ & $1 \cdot 8$ & $0 \cdot 4$ & $2 \cdot 3$ & $4 \cdot 0$ & $11 \cdot 8$ & Small stature \\
\hline $\mathbf{N}$ & $\mathbf{M}$ & 30 mths & $0 \cdot 4$ & $\mathbf{0} \cdot \mathbf{8}$ & $0 \cdot 7$ & $1 \cdot 0$ & $1 \cdot 8$ & $10 \cdot 7$ & $12 \cdot 9$ & $15 \cdot 2$ & Small stature; attacks of diarrhoea and vomiting \\
\hline $\mathbf{O}$ & $\mathbf{M}$ & $\begin{array}{l}5 \text { yrs } \\
1 \mathrm{mth}\end{array}$ & $0 \cdot 2$ & $0 \cdot 4$ & $0 \cdot 6$ & $0 \cdot 9$ & $1 \cdot 4$ & $6 \cdot 3$ & $10 \cdot 2$ & $15 \cdot 3$ & $\begin{array}{l}\text { Small stature; cannot tolerate long intervals } \\
\text { without food }\end{array}$ \\
\hline $\mathbf{P}$ & $\mathbf{F}$ & $\begin{array}{l}5 \text { yrs } \\
6 \text { mths }\end{array}$ & $0 \cdot 6$ & 0.9 & $1 \cdot 1$ & $1 \cdot 5$ & $2 \cdot 7$ & $6 \cdot 1$ & $10 \cdot 4$ & $11 \cdot 3$ & $\begin{array}{l}\text { Multiple congenital abnormalities; short } \\
\text { stature, mental retardation }\end{array}$ \\
\hline $\mathbf{Q}$ & $\mathbf{M}$ & $\begin{array}{l}5 \text { yrs } \\
6 \text { mths }\end{array}$ & $0 \cdot 6$ & $0 \cdot 9$ & $1 \cdot 2$ & $1 \cdot 4$ & $1 \cdot 8$ & $4 \cdot 8$ & $6 \cdot 7$ & $10 \cdot 0$ & $\begin{array}{l}\text { Short stature, headaches; fasting blood sugars } \\
\text { less than normal }\end{array}$ \\
\hline $\mathbf{R}$ & $\mathbf{M}$ & $\begin{array}{l}8 \text { yrs } \\
1 \text { mth }\end{array}$ & $0 \cdot 5$ & $1 \cdot 2$ & $1 \cdot 3$ & $1 \cdot 5$ & $2 \cdot 3$ & $9 \cdot 0$ & $12 \cdot 9$ & $16 \cdot 0$ & Short stature: recurrent bronchit is \\
\hline $\mathbf{S}$ & $\mathbf{F}$ & $\begin{array}{l}8 \text { yrs } \\
8 \text { mths }\end{array}$ & $1 \cdot 0$ & $1 \cdot 8$ & $1 \cdot 4$ & $3 \cdot 0$ & $3 \cdot 4$ & $8 \cdot 3$ & $9 \cdot 5$ & $14 \cdot 1$ & $\begin{array}{l}\text { Short stature; history of convulsions and } \\
\text { attacks of drowsiness, many coughs and } \\
\text { mild febrile illnesses }\end{array}$ \\
\hline $\mathbf{T}$ & $\mathbf{F}$ & 13 yrs & $2 \cdot 0$ & $2 \cdot 6$ & $2 \cdot 2$ & $3 \cdot 4$ & $1 \cdot 0$ & $11 \cdot 4$ & $15 \cdot 4$ & $14 \cdot 7$ & Short stature; no secondary sexual changes \\
\hline $\mathbf{U}$ & $\mathbf{M}$ & $\begin{array}{l}11 \text { mths } \\
\text { Repeated } \\
\text { at } \\
26 \text { mths }\end{array}$ & $\begin{array}{l}0 \cdot 2 \\
0 \cdot 4\end{array}$ & $\begin{array}{l}0 \cdot 2 \\
0 \cdot 8\end{array}$ & $\begin{array}{l}0 \cdot 6 \\
0 \cdot 9\end{array}$ & $\begin{array}{l}1 \cdot 0 \\
0 \cdot 8\end{array}$ & $\begin{array}{l}1 \cdot 0 \\
0 \cdot 7\end{array}$ & $\begin{array}{l}2 \cdot 2 \\
6 \cdot 1\end{array}$ & $\begin{array}{l}9 \cdot 3 \\
4 \cdot 6\end{array}$ & $\begin{array}{l}8 \cdot 8 \\
7 \cdot 6\end{array}$ & $\begin{array}{l}\text { Failure to thrive } \\
\text { Now of short stature }\end{array}$ \\
\hline $\mathbf{v}$ & $\mathbf{M}$ & $\begin{array}{l}25 \text { mths } \\
\text { Repeated } \\
\text { at } \\
27 \text { mths }\end{array}$ & $\begin{array}{l}0.9 \\
0 \cdot 4\end{array}$ & $\begin{array}{l}0.5 \\
0.8\end{array}$ & $\begin{array}{l}0.4 \\
0.5\end{array}$ & $\begin{array}{l}0.4 \\
0.9\end{array}$ & $\begin{array}{l}1.0 \\
0.9\end{array}$ & $\begin{array}{l}2 \cdot 4 \\
5 \cdot 2\end{array}$ & $\begin{array}{l}2 \cdot 0 \\
3 \cdot 7\end{array}$ & $\begin{array}{l}3 \cdot 0 \\
7 \cdot 5\end{array}$ & Short stature and failure to thrive \\
\hline $\mathbf{w}$ & $\mathbf{M}$ & $\begin{array}{l}2 \text { yrs } \\
7 \text { mths }\end{array}$ & $0 \cdot 2$ & $0 \cdot 2$ & $0 \cdot 8$ & $1 \cdot 7$ & $1 \cdot 1$ & $6 \cdot 6$ & $12 \cdot 2$ & $18 \cdot 5$ & $\begin{array}{l}\text { Short stature and convulsions associated with } \\
\text { hypoglycaemia; at autopsy of sibling who } \\
\text { died during second stage of labour, no } \\
\text { adrenal tissue found macroscopically in } \\
\text { abdominal cavity, though histological } \\
\text { examination showed small amounts of } \\
\text { primitive adrenal tissue situated above left } \\
\text { kidney }\end{array}$ \\
\hline
\end{tabular}

(Daniel, 1941), but it is not specific for adrenal deficiency.

The need for normal values in response to ACTH was commented on by O'Sullivan, Reddy and Farrell (1961) when they were studying adrenal function in mongols and suspected that their findings indicated hypofunction. It seems possible, too, that in patients such as those described by Greenberg (1958), a diagnosis of Addison's disease could be reached sooner by the use of a wellstandardized ACTH test that would enable detection of partial adrenal failure.

Without doubt the ACTH test is the most important one in the diagnosis of adrenal cortical hypofunction, and the results of this preliminary study suggest that the condition may be commoner in children than has been suspected in the past.
We thank the Consultant Staff for permission to investigate their patients. We wish to thank Mr. R. Gardner and his technicians for their help. We are particularly grateful to Dr. M. Kinsbourne for his co-operation, and to the Nursing Staff who made all the urine collections. One of us (R.W.H.E.) received financial assistance from the Research Committee of The Hospital for Sick Children. We are indebted to Dr. C. R. Tribe, Stoke Mandeville Hospital, Aylesbury, for details of the autopsy on the sibling of Patient $\mathbf{W}$.

\section{REFERENCES}

Appleby, J. I., Gibson, G., Norymberski, J. K. and Stubbs, R. D. (1955). Indirect analysis of corticosteroids. I. The determination of 17-hydroxycorticoids. Biochem. J., 60, 453.

Bayliss, R. I. S. (1955). Factors influencing adrenocortical activity in health and disease. Brit. med. J., 1, 495.

Daniel, W. A. (1941). A study of insulin tolerance and glucose tolerance tests on normal infants. J. Pediat., 19, 789.

Ely, R. S., Raile. R. B. Bray, P. F. and Kelley, V. C. (1954). Studies of 17 -hydroxycorticosteroids. IV. Evaluation of a standard of 17-hydroxycorticosteroids. IV. Evahuation of a standard Pediatrics, 13, 403 . 
Gordon, D., Horwitt. B. N. and Segaloff. A. (1954). Adrenal resbonse to ACTH in various clinical conditions. J. clin. Endocr., 14. 297.

Gottfried, S. P., Bogin. M. and Levycky, N. V. (1957). The effect of corticotropin on the activity of the adrenal cortex of the mak

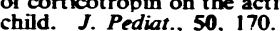

Greenberg, R. E. (1958). Addison's disease in children. Report of two cases. ibid.. 52. 54 .

Laidlaw. J. C.. Reddy. W. J.. Jenkins, D., Haydar, N. A., Renold, A. E. and Thorn, G. W. (1955). Advances in the diagnosis of altered states of adrenocortical function. New Engl. J. Med. 253,747

Meakin, J. W., Tantongco, M. S., Crabbé, J., Bayles. T. B. and Nelson. D. H. (1960). Pituitary-adrenal function following longterm steroid therapy. Amer. J. Med.. 29. 459.

Velson. D. H.. Samuels. L. T., Willardson. D G. and Tyker, F. H. (1951). The levels of 17-hydroxycorticosteroids in peripheral blood of human subjects. J. clin. Endocr., 11, 1021.
Norymberski, J. K.. Stubbs, R. D. and West, H. F. (1953). Assess ment of adrenocortical activity by assay of 17 -ketogenic steroids in urine. Lan.et, 1. 1276.

O'Sullivan, J. B., Reddy, W. J. and Farrell, M. J. (1961). Adrenal function in mongolism. Amer. J. Dis. Child.. 101, 37.

Prout, M. and Snaith. A. H. (1958). Urinary excretion of 17-keto steroids in children. Arch. Dis. Childh., 33, 301.

Prunty. F. T. G. (1956). Chemical and clinical problems of the adrenal cortex. Brit. med J., 2, 615 and 673 .

Steiker, D. D. Bongiovanni, A. M., Eberkein, W. R. and Leboeuf, G (1961). Adrenocortical and adrenocorticotropic function in children. J. Pediat., 59, 884.

Szczepańska, H. and Sapiocha, J. (1959). Addison's disease with hypofunction of the parathyroid glands. Arch. Dis. Childh. 34, 498.

Talbot, N. B. Sobel, E. H. McArthur, J. W, and Crawford, J. D. (1952) Functional Endocrinology from Birth through Adolescence. Harvard University Press, Cambridge, Massachusetts. 